\title{
Dietary cellulose has no effect on the regeneration of hemoglobin in growing rats with iron deficiency anemia
}

M. Catani,

O.M.S. Amâncio,

U. Fagundes-Neto and M.B. Morais
Disciplina de Gastroenterologia Pediátrica, Departamento de Pediatria, Escola Paulista de Medicina, Universidade Federal de São Paulo, São Paulo, SP, Brasil

\section{Correspondence}

M.B. Morais

Rua Araioses, 75

05442-010 São Paulo, SP

Brasil

Fax: +55-11-5549-6124

E-mail: mbmorais.dped@epm.br

Research supported by CNPq.

Publication supported by FAPESP.

Received August 8, 2002

Accepted January 6, 2003

\begin{abstract}
The objective of the present study was to determine the effect of cellulose on intestinal iron absorption in rats during recovery from iron deficiency anemia. Twenty-one-day-old male Wistar-EPM rats were fed an iron-free ration for two weeks to induce anemia. At 5 weeks of age, the rats were divided into two groups (both groups receiving $35 \mathrm{mg}$ of elemental iron per $\mathrm{kg}$ diet): cellulose group $(\mathrm{N}=$ 12), receiving a diet containing $100 \mathrm{~g}$ of cellulose $/ \mathrm{kg}$ and control $(\mathrm{N}=$ 12), receiving a diet containing no cellulose. The fresh weight of the feces collected over a 3-day period between the 15th and 18th day of dietary treatment was $10.7 \pm 3.5 \mathrm{~g}$ in the group receiving cellulose and $1.9 \pm 1.2 \mathrm{~g}$ in the control group $(\mathrm{P}<0.001)$. Total food intake was higher in the cellulose group ( $343.4 \pm 22.0 \mathrm{~g})$ than in the control (322.1 $\pm 13.1 \mathrm{~g}, \mathrm{P}=0.009$ ) during the 3 weeks of dietary treatment. No significant difference was observed in weight gain (cellulose group $=$ $132.8 \pm 19.2$, control $=128.0 \pm 16.3 \mathrm{~g}$ ), hemoglobin increment (cellulose group $=8.0 \pm 0.8$, control $=8.0 \pm 1.0 \mathrm{~g} / \mathrm{dl}$ ), hemoglobin level (cellulose group $=12.3 \pm 1.2$, control $=12.1 \pm 1.3 \mathrm{~g} / \mathrm{dl}$ ) or in hepatic iron levels (cellulose group $=333.6 \pm 112.4$, control $=398.4 \pm 168.0$ $\mu \mathrm{g} / \mathrm{g}$ dry tissue). We conclude that cellulose does not adversely affect the regeneration of hemoglobin, hepatic iron level or the growth of rats during recovery from iron deficiency anemia.
\end{abstract}

The role of dietary fiber in the promotion of health has received growing attention in recent years, not only because of its immediate effects, but also because of its probable role in the prevention of disease $(1,2)$. The recommendation for infants is that the consumption of dietary fiber should begin only after the age of two years (3). On the other hand, there are no recommendations for infants that are less than two years of age due to the possible negative effects of excessive
Key words

- Iron deficiency

- Dietary fiber

- Cellulose

- Iron absorption consumption of dietary fiber on growth and on the intestinal absorption of minerals, including iron (4).

Studies (5) of chronic constipation during infancy have demonstrated that more than half of the 5-year-old patients attended presented constipation starting at less than 1 year of age. For this reason, food rich in fiber is being recommended for weaned infants, especially insoluble fiber, in order to prevent constipation. However, food rich in fiber 
may reduce the absorption of minerals $(4,6)$, possibly contributing to the development of iron deficiency, which is currently the most prevalent nutritional deficiency in Brazil and in other developing countries (7).

Studies that evaluate the interaction of fibers with iron in the intestine do not present fully consistent results and some of them analyzed the effect of fibers on iron absorption on the basis of a single meal test (8) or on the basis of the apparent absorption of this mineral $(6,9-11)$. The intestinal bioavailability and absorption of iron can be evaluated by measuring the regeneration of hemoglobin in anemic rats previously submitted to an iron-free diet (12).

The aim of the present study was to determine the effect of dietary insoluble fiber (cellulose) on intestinal iron absorption measured on the basis of the regeneration of hemoglobin (12), on dietary intake and on the growth of rats with iron deficiency anemia.

Twenty-one-day-old male Wistar-EPM rats $(\mathrm{N}=24)$ were fed the AIN-93G iron-free diet (13) for a period of 2 weeks to induce

Table 1. Composition of the AIN-93G (10) diet for growing rats modified by increasing the quantity of cellulose (experimental diet) and by replacing cellulose with corn starch (control diet).

\begin{tabular}{lcc}
\hline Ingredients & Cellulose diet $(\mathrm{g} / \mathrm{kg})$ & Control diet $(\mathrm{g} / \mathrm{kg})$ \\
\hline Cellulose & 100.00 & 0.00 \\
Corn starch & 497.46 & 597.46 \\
Casein & 200.00 & 200.00 \\
Sucrose & 82.45 & 82.45 \\
Soy bean oil & 70.00 & 70.00 \\
L-cystine & 3.00 & 3.00 \\
Choline tartrate & 2.50 & 2.50 \\
T-butylhydroquinone & 0.014 & 0.014 \\
Vitamin mixture $\left(\right.$ Roche $^{\circledR}{ }^{\circledR a}$ & 10.00 & 10.00 \\
Mineral mixture $\left(\text { Roche }^{\circledR}\right)^{\mathrm{b}}$ & 35.00 & 35.00 \\
\hline
\end{tabular}

aComposition: $30 \mathrm{mg}$ niacin, 15 pantothenic acid, $6 \mathrm{mg}$ vitamin $\mathrm{B} 6,5 \mathrm{mg}$ thiamine, 6 mg riboflavin, $2 \mathrm{mg}$ folic acid, $750 \mu \mathrm{g}$ vitamin K, $200 \mu \mathrm{g}$ D-biotin, $25 \mu \mathrm{g}$ vitamin B12, $4000 \mu \mathrm{g}$ vitamin $\mathrm{A}, 1000 \mu \mathrm{g}$ vitamin $\mathrm{D} 3,75 \mu \mathrm{g}$ vitamin $\mathrm{E}$.

bComposition: essential minerals - $35 \mathrm{mg}$ iron, $5000 \mathrm{mg}$ calcium, $1561 \mathrm{mg}$ phosphate, $3600 \mathrm{mg}$ potassium, $300 \mathrm{mg}$ sulfur, $1019 \mathrm{mg}$ sodium, $1571 \mathrm{mg}$ chlorine, $507 \mathrm{mg}$ magnesium, $30 \mathrm{mg}$ zinc, $10 \mathrm{mg}$ manganese, $5 \mathrm{mg}$ copper, $0.2 \mathrm{mg}$ iodine, $0.15 \mathrm{mg}$ molybdenum, $0.15 \mathrm{mg}$ selenium, and potentially beneficial minerals $-5 \mathrm{mg}$ silicone, 1 $\mathrm{mg}$ chromium, $1 \mathrm{mg}$ fluorine, $0.5 \mathrm{mg}$ nickel, $0.1 \mathrm{mg}$ lithium, $0.1 \mathrm{mg}$ vanadium. iron deficiency anemia (12). For the duration of the experiment the animals received diet and water deionized by filtration through the MilliQ Plus system (Millipore Corp., São Paulo, SP, Brazil) ad libitum. The rats were kept in acrylic metabolic cages (Nalgene 650-0100, Rochester, NY, USA), under a 12-h light cycle and a temperature of $23 \pm$ $1{ }^{\circ} \mathrm{C}$.

After receiving this iron-free diet for 2 weeks, the animals - now 5 weeks old - were divided randomly into two groups of 12 rats each: cellulose group receiving a diet with cellulose (100 g/kg of diet), and control group receiving a control diet in which cellulose was replaced with corn starch, as suggested in the literature (14). The diets with and without cellulose were both prepared according to American Institute of Nutrition recommendations (AIN-93G) (13) and with the same amount of iron ( $35 \mathrm{mg}$ of elemental iron per $\mathrm{kg}$ of diet in the form of iron sulfate), as shown in Table 1.

After weeks 1, 2 and 3 of the imposed diets both groups were weighed and a blood sample was taken from the tail to determine hemoglobin and hematocrit values. During this period, the diet intake was measured at 3 -day intervals. Between the 15th and 18th day of the diet, the total accumulated feces from both groups were collected for weighing. On the 21 st day of the diet, the animals were sacrificed and the level of hepatic iron was determined.

Hemoglobin was determined by the cyanomethemoglobin method and hematocrit by the method of Wintrobe et al. (15). Hepatic iron levels were determined after liquid digestion of dry tissue by atomic absorption spectrophotometry (Perkin-Elmer - 5.100, Norwalk, CT, USA) (16).

Data were analyzed statistically by the Student $t$-test using the Jandel-Sigma Stat program, with the level of significance set at $\mathrm{P}<0.05$.

When the test diets with iron were initiated, body weight was $97.7 \pm 10.5 \mathrm{~g}$ for the 
cellulose group and $96.2 \pm 9.1 \mathrm{~g}$ for the control group $(\mathrm{P}=0.702)$ and the hemoglobin and hematocrit values were similar (4.2 $\pm 0.9 \mathrm{~g} / \mathrm{dl}$ and $18.6 \pm 2.6 \%$ for the cellulose group and $4.0 \pm 0.76 \mathrm{~g} / \mathrm{dl}$ and $17.6 \pm 2.7 \%$ for the control group, respectively, with no statistical difference between groups for either measurement). Therefore, the two groups were homogenous before being submitted to the specific diets.

The fresh weight of the feces collected between the 15th and 18th day of dietary treatment was $10.7 \pm 3.5 \mathrm{~g}$ for the cellulose group and $1.9 \pm 1.2 \mathrm{~g}$ for the control group.

The total dietary intake during the 3 weeks of dietary treatment was higher for the cellulose group compared to control $(\mathrm{P}=0.009)$. Examination of these 3-day intervals showed that the cellulose group ingested significantly more food (about 10\%) during the periods between the 6th and 9th day $(\mathrm{P}=0.049)$ and the 9th and 12th day $(\mathrm{P}=0.018)$.

No statistically significant difference in body weight was observed between groups weekly or for the 3-week period. After 3 weeks of diet, body weight was $225.7 \pm 22.8 \mathrm{~g}$ for the cellulose group and $229.0 \pm 23.7 \mathrm{~g}$ for the control.

During the 3 weeks of dietary treatment no statistically significant difference in hemoglobin or hematocrit was observed between groups during any of the 3 weeks. At the end of the experiment, hemoglobin was $12.3 \pm 1.2 \mathrm{~g} / \mathrm{dl}$ for the experimental group and $12.1 \pm 1.3 \mathrm{~g} / \mathrm{dl}$ for the control. Hematocrit was $42.6 \pm 1.9 \%$ for the experimental group and $42.6 \pm 1.9 \%$ for the control.

Fresh liver weight was $9.9 \pm 1.9 \mathrm{~g}$ for the cellulose group and $10.6 \pm 1.5 \mathrm{~g}$ for the control, and iron levels determined in dried tissue were $333.6 \pm 112.4 \mu \mathrm{g} / \mathrm{g}$ for the experimental group and $398.4 \pm 168.0 \mu \mathrm{g} / \mathrm{g}$ for the control. Again, no significant differences were detected between the two groups.

The main objective of this study was to determine whether cellulose (insoluble fiber) reduces the intestinal absorption of iron.
This subject is of great importance since the consumption of fiber during the first few years of life may have negative repercussions on childhood growth and development by interfering with food intake and iron absorption (4). This concern is the result of published evidence linking fiber to reduced iron absorption based on several proposed explanations: the binding of divalent metals such as iron to the fibers $(6,9)$, an increase in intestinal peristalsis, and the formation of insoluble compounds with certain organic acids, such as phytate $(1,8,10)$. However, it is worth remembering that many of these studies were carried out in vitro (9) and were based on a single meal test $(8,9)$ or on estimated intestinal absorption $(10,11)$. In the present study, a hemoglobin repletion model was employed as an indicator of intestinal iron absorption. This model is based on the evaluation of the effect during the period corresponding to that required for the recovery from iron deficiency anemia, when a reduction in intestinal iron absorption would be accompanied by a reduction in the hemoglobin regeneration rate. Because the animals chosen were growing, it was also possible to evaluate the effect of cellulose on food intake and growth.

Cellulose was added to the experimental diet in a quantity of $100 \mathrm{~g} / \mathrm{kg}$ diet, while in the control group cellulose was replaced with corn starch (14). The density of insoluble fiber (cellulose), of about $25 \mathrm{~g}$ per 1000 calories of experimental diet, is greater than the quantity recommended for humans, which should ideally be between 8 and $10 \mathrm{~g}$ of fiber per 1000 calories (17). The pilot study carried out in our laboratory compared the efficacy of the addition of $35 \mathrm{mg}$ or 105 $\mathrm{mg}$ of elemental iron to the diet used during the period of recovery from iron deficiency anemia in rats. We demonstrated that both iron quantities aided in the recovery from anemia over a period of 3 weeks. Because of this result, the $35 \mathrm{mg}$ quantity of iron was chosen so that a weaker effect of fiber retard- 
ing the reversal of iron deficiency anemia could be detected more easily than if a larger quantity of iron was used.

The level of hemoglobin of approximately $4.0 \mathrm{~g} / \mathrm{dl}$ confirmed that the diet period of 2 weeks without iron was sufficient to induce iron deficiency anemia, as reported in the literature (12). The 3-week period for hemoglobin repletion was also adequate since the hemoglobin level attained of $12.0 \mathrm{~g} / \mathrm{dl}$ is the value expected for 8 -week-old rats. The results show that, in addition to the final hemoglobin value being similar in the experimental and control groups after 3 weeks of dietary treatment, the weekly increase in hemoglobin and in hematocrit was also similar, ruling out the possibility that the normalization of these hematic parameters had developed more slowly in the group fed the diet rich in cellulose.

Our results agree with those reported in the few studies that have analyzed the regeneration of hemoglobin in rats, pigs and chickens fed diets containing different quantities of fiber provided by cellulose, wheat bran or other food stuffs $(6,18,19)$.

Our study, which evaluated the effect of a diet rich in fiber during the period of recovery from iron deficiency anemia, found no evidence of any reduction in intestinal iron absorption during this process. It is possible to speculate, from an experimental perspective, that this result, observed over a period of 3 weeks, provides data of greater consistency with respect to the interaction between iron and cellulose. Our results also agree with the only other study published that used the same experimental model which also showed no evidence of reduced intestinal absorption of iron in the presence of dietary cellulose (20).

Another aspect related to the consumption of a diet rich in dietary fiber is a possible reduction of food intake that may cause a reduction in growth. In our study, the total food intake of the rats fed a ration rich in cellulose was found to be greater than that of the control group. It is probable that the animals fed a fiber-rich diet were compensating so as to meet their energy and iron needs. It is important to emphasize that the increase in weight was similar for the animals from both groups evaluated during the 3 weeks of observation. There was no reduction in the intake of food or in growth when rats with iron deficiency anemia were fed a diet rich in cellulose.

This study, carried out with immature growing rats with iron deficiency anemia, did not show any reduction in intestinal iron absorption (indicated by the regeneration of hemoglobin), in food intake or in growth associated with the use of a diet rich in cellulose. It is also important to emphasize that studies on human infants are necessary to determine the safety of the use of weaning foods rich in dietary fiber, as observed in the present experimental study.

\section{References}

1. Williams CL (1995). Importance of dietary fiber in childhood. Journal of the American Dietetic Association, 95: 1140-1149.

2. American Gastroenterological Association Medical Position Statement (2000). Impact of dietary fiber on colon and cancer occurrence. Gastroenterology, 118: 1233-1234.

3. Williams CL, Bollella M \& Wynder El (1995). A new recommendation for dietary fiber in childhood. Pediatrics, 96: 985-988.

4. Agostoni C, Riva E \& Giovannini M (1995). Dietary fiber in weaning foods of young children. Pediatrics, 96: 1002-1005.

5. Morais MB \& Maffei HVL (2000). Constipação intestinal. Jornal de Pediatria, 76 (Suppl 2): S147-S156.

6. Frolich W (1993). Bioavailability of minerals from cereals. In: Spiller
GA (Editor), Handbook of Dietary Fiber in Human Nutrition. CRC Press, Boca Raton, FL, USA, 209-244.

7. WHO (1998). Measuring Health. The World Health Report. World Health Organization, Geneva, Switzerland, 39-60.

8. Simpson KM, Morris ER \& Cook JD (1981). The inhibitory effect of bran on iron absorption in man. American Journal of Clinical Nutrition, 34: 1469-1478.

9. Ismail-Beigi F, Faraji B \& Reinhold JG (1977). Binding of zinc and iron to wheat bread, wheat bran, and their components. American Journal of Clinical Nutrition, 30: 1721-1725.

10. Galibois I, Desrosiers T, Guévin N, Lavigne C \& Jacques H (1994). Effects of dietary fibre mixtures on glucose and lipid metabolism 
and on mineral absorption in the rat. Annals of Nutrition and Metabolism, 38: 203-211.

11. Wang $Y$, Funk MA, Garleb KA \& Chevreau N (1994). The effect of fiber source in enteral products on fecal weight, mineral balance, and growth rate in rats. Journal of Parenteral and Enteral Nutrition, 18: 340-345.

12. Forbes $A L$, Arnaud MJ, Chichester CO, Cook JD, Harrison BN, Hurrell RF, Kahn SG, Morris ER, Tanner JT \& Whittaker P (1989). Comparison of in vitro, animal, and clinical determinations of iron bioavailability: International Nutritional Anemia Consultative Group Task Force Report on Iron Bioavailability. American Journal of Clinical Nutrition, 49: 225-238.

13. Reeves PG, Nielsen FH \& Fahey GC (1993). Purified diets for laboratory rodents: final report of the American Institute of Nutrition - Ad Hoc Writing Committee on the Reformulation of the AIN-76: A rodent diet. Journal of Nutrition, 123: 1939-1951.

14. Borel MJ, Smith SH, Brigham DE \& Beard JL (1991). The impact of varying degrees of iron nutriture on several functional consequences of iron deficiency in rats. Journal of Nutrition, 121: 729-736.
15. Wintrobe M, Mollin D, Herbert V et al. (1968). Anemias nutricionales. Organización Mundial de la Salud, Serie Informe Técnicos, 405: 539.

16. Marks GE, Moore CE, Kanabrocki EL, Oester YT \& Kaplan E (1971). Determination of trace elements in human tissue. I. Cd, Fe, $\mathrm{Zn}, \mathrm{Mg}$ and Ca. Applied Spectroscopy, 26: 523-527.

17. Vannucchi H (1990). Fibra alimentar ou fibra da dieta. In: Vannucchi H, Menezes EW \& Lajolo FM (Editors), Sociedade Brasileira de Alimentação e Nutrição. Aplicações das Recomendações Nutricionais Adaptadas à População Brasileira. Legis Suma, Ribeirão Preto, $\mathrm{SP}$, Brazil.

18. Frolich W \& Lyso A (1983). Bioavailability of iron from wheat bran in pigs. American Journal of Clinical Nutrition, 37: 31-36.

19. Fly AD, Czarnecki-Maulden GL, Fahey GC \& Titgemeyer EC (1996). Hemicellulose does not affect iron bioavailability in chicks. Journal of Nutrition, 126: 308-316.

20. Gordon DT \& Chao LS (1984). Relationship of components in wheat bran and spinach to iron bioavailability in the anemic rat. Journal of Nutrition, 114: 526-535. 